(C) 2022, The Authors. Published by Elsevier Inc. and Fass Inc. on behalf of the American Dairy Science Association ${ }^{\circledR}$. This is an open access article under the CC BY license (http://creativecommons.org/licenses/by/4.0/).

\title{
Whey fermented by Enterococcus faecalis M157 exhibits antiinflammatory and antibiofilm activities against oral pathogenic bacteria
}

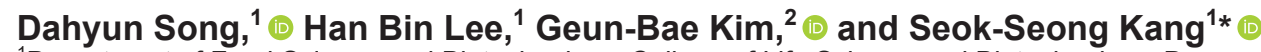 \\ ${ }^{1}$ Department of Food Science and Biotechnology, College of Life Science and Biotechnology, Dongguk University-Seoul, Goyang 10326 , \\ Republic of Korea \\ ${ }^{2}$ Department of Animal Science and Technology, Chung-Ang University, Anseong 17546, Republic of Korea
}

\begin{abstract}
The aim of the present study was to investigate the antiinflammatory and antibiofilm effects of whey fermented by Enterococcus faecalis M157 (M157-W) against oral pathogenic bacteria. The M157-W significantly inhibited IL-1 $\beta$, IL-6, and nitric oxide induced by the lipopolysaccharide of Porphyromonas gingivalis in RAW 264.7 cells. The M157-W also inhibited the production of IL-1 $\beta$ and IL-8 in human periodontal ligament cells. Treatment with M157-W suppressed the phosphorylation of mitogen-activated protein kinases as well as the activation of nuclear factor- $\kappa \mathrm{B}$ in RAW 264.7 cells stimulated by $P$. gingivalis lipopolysaccharide. Furthermore, M157-W dose-dependently inhibited Streptococcus mutans biofilm, whereas unfermented whey did not inhibit the biofilm. Treatment with M157-W significantly suppressed gtfB, gtfC, and gtfD gene expression in $S$. mutans compared with the control $(0 \mu \mathrm{g} / \mathrm{mL})$, indicating that M157-W inhibits $S$. mutans biofilm formation by reducing the synthesis of extracellular polymeric substances. Collectively, these results suggest that M157-W has antiinflammatory and antibiofilm activities against oral pathogenic bacteria.
\end{abstract} Key words: whey, fermentation, Enterococcus faecalis, oral disease

\section{INTRODUCTION}

Milk predominantly consists of 2 major proteins, casein and whey, which account for approximately 80 and $20 \%$ of the total protein in milk, respectively (Zhou et al., 2015). Although whey was first considered a by-product of cheese production, it is now recognized as a potential source of bioactive components, such as $\alpha$-LA, $\beta$-LG, glycomacropeptide, immunoglobulins, lac-

Received September 1, 2021.

Accepted November 29, 2021.

*Corresponding author: sskang@dgu.ac.kr toferrin, and serum albumin (Madureira et al., 2007). Whey contains several bioactive constituents that promote health; therefore, it is used in various commercial food and dairy products (Minj and Anand, 2020). Peptides derived from whey have been reported to exhibit antioxidant, antibacterial, immunomodulatory, and antihypertensive effects (Madureira et al., 2010). Furthermore, whey protein hydrolysates have been shown to exhibit potential antiinflammatory activity (Tavares et al., 2013). Although whey itself exhibits several beneficial effects on human health, fermentation of whey by bacteria, such as lactic acid bacteria, has also been reported to enhance its biological functions. For instance, whey fermented by various lactic acid bacteria including Pediococcus, Lactobacillus, and Weissella suppresses preadipocyte differentiation (Lee et al., 2021a,b). However, no studies are available about the effects of whey fermented by Enterococcus faecalis on oral pathogenic bacteria-mediated inflammation and biofilm as well as the associated underlying mechanisms.

Oral diseases have serious health and economic burdens (Peres et al., 2019). The most common oral diseases, periodontitis and dental caries, are crucially involved as a major cause of tooth loss in adults (Strauss et al., 2019). Periodontitis is a chronic inflammation caused by multiple pathogenic bacteria, including Porphyromonas gingivalis, which is considered the main pathogen involved in the development of chronic periodontitis. Lipopolysaccharide of $P$. gingivalis is a major virulence factor for chronic periodontitis because it has been shown to induce the release of inflammatory mediators, such as IL-1 $\beta$, IL-6, and nitric oxide (NO) (Nativel et al., 2017; Zhang et al., 2018). Dental caries is readily caused by formation of Streptococcus mutans biofilm accompanied with acidification and demineralization (Pitts et al., 2017). To enhance biofilm formation on tooth surfaces, S. mutans synthesizes glucosyltransferases that produce extracellular polymeric substances (EPS) by mixing insoluble and soluble glucans using carbohydrates such as sucrose (Bowen and Koo, 2011). The extracellular glucan matrix is the most 
important component that enhances $S$. mutans biofilm by adhering to the tooth surface (Schilling and Bowen, 1992). Moreover, EPS in biofilm can provide S. mutans with microenvironments for the bacterial growth, metabolism, and survival to be more resistant to harsh environmental conditions (Simón-Soro and Mira, 2015).

Lactic acid bacteria have been used as a starter for fermented foods. During fermentation, enzymatic reactions are associated with the production of metabolites such as acetaldehyde, hydrogen peroxide, organic acids, and peptides (Garcia-Cano et al., 2019). Moreover, many lactic acid bacteria function as probiotics exhibiting several health benefits, such as intestinal health improvement, immune response enhancement, and cancer prevention (Kechagia et al., 2013). Some lactic acid bacteria are also beneficial in preventing and treating oral diseases. Lactobacillus paracasei and L. salivarius have been shown to exhibit antibacterial activities against $P$. gingivalis and $S$. mutans (Lai et al., 2021). Furthermore, probiotic strains of Lactobacillus and Bifidobacterium have been reported to reduce the adhesion and invasion of $P$. gingivalis to gingival epithelial cells, thereby preventing biofilm formation (Albuquerque-Souza et al., 2019; Ishikawa et al., 2020). Mendi et al. (2016) also showed that L. rhamnosus inhibited $P$. gingivalis-induced IL-8 expression.

Although biotransformation of whey by lactic acid bacteria has been reported to demonstrate inhibitory effects on the differentiation of 3T3-L1 preadipocytes in vitro (Lee et al., 2021a,b), the biological activities of biotransformed whey against pathological microorganisms have not been widely documented. Among the lactic acid bacteria, enterococci including E. faecalis have been extensively studied as potential candidates of probiotics (Hanchi et al., 2018). In addition, they are also involved in the fermentation activity of dairy products (Hanchi et al., 2014). Since it is known that $E$. faecalis has beneficial effects on improving human health during fermentation, we investigated the inhibition $P$. gingivalis LPS-induced inflammatory responses and biofilm formation by $S$. mutans using whey fermented by E. faecalis M157.

\section{MATERIALS AND METHODS}

\section{Fermentation of Whey by E. Faecalis}

Enterococcus faecalis M157 was grown in de Man, Rogosa, and Sharpe broth (Neogen) at $37^{\circ} \mathrm{C}$ for 24 h. Whey powder was obtained from Samik Dairy and Food Co. Ltd., and $3 \mathrm{~g}$ of whey powder was suspended in $27 \mathrm{~mL}$ of distilled water. To avoid bacterial contamination, the whey suspension was immersed in a water bath at $80^{\circ} \mathrm{C}$ for 1 min. During pasteurization, the whey suspension was gently rotated several times. Bacterial contamination was determined by plating on nutrient agar. The whey suspension was then inoculated with E. faecalis M157 and incubated at $37^{\circ} \mathrm{C}$ for $24 \mathrm{~h}$. After the incubation, the whey suspension was filtered to remove bacteria and the cell-free supernatants were obtained, evaporated, and dried using a spray dryer (B-290, Buchi). The whey fermented by $E$. faecalis M157 (M157-W; $1 \mathrm{mg}$ ) was resuspended in 1 $\mathrm{mL}$ of distilled water, centrifuged, and the supernatant was collected and adjusted to $\mathrm{pH} 6.5$ with $1 \mathrm{~N} \mathrm{NaOH}$. M157-W was filtered using a $0.2-\mu \mathrm{m}$ syringe filter and stored at $-80^{\circ} \mathrm{C}$ until used.

\section{Cell Culture}

The RAW 264.7 murine macrophage cells were purchased from American Type Cell Culture (ATCC) and maintained in Dulbecco's modified Eagle's medium (Welgene) supplemented with $10 \%$ fetal bovine serum and $100 \mathrm{U} / \mathrm{mL}$ penicillin and $100 \mu \mathrm{g} / \mathrm{mL}$ streptomycin (HyClone) at $37^{\circ} \mathrm{C}$ in a $5 \% \mathrm{CO}_{2}$-humidfied incubator. Human periodontal ligament (PDL) cells were kindly provided by Seung Hyun Han (Seoul National University, Seoul, Korea) and grown in minimal essential medium, $\alpha$ modification (Welgene) containing $10 \%$ fetal bovine serum and the aforementioned antibiotics. The RAW 264.7 cells and PDL cells were treated with appropriate concentrations of M157-W $(0,0.1,1,10$, or $100 \mu \mathrm{g} / \mathrm{mL}$ and $100 \mu \mathrm{g} / \mathrm{mL}$, respectively) with or without $1 \mu \mathrm{g} / \mathrm{mL}$ of $P$. gingivalis LPS. The 3 -(4,5-dimethylthiazol-2-yl)-2,5-diphenyltetrazolium bromide (MTT) assay did not show any significant difference in the viability of RAW 264.7 cells and PDL cells (data not shown). After treatment, the expression of IL-1 $\beta$, IL-6, and NO in RAW 264.7 cells and IL-1 $\beta$, IL-6, and IL-8 in PDL cells was determined. In addition, RAW 264.7 cells were treated with unfermented whey $(0,0.1$, 1,10 , and $100 \mu \mathrm{g} / \mathrm{mL}$ ) with or without $1 \mu \mathrm{g} / \mathrm{mL}$ of $P$. gingivalis LPS for $3 \mathrm{~h}$.

\section{Quantitative Reverse-Transcription PCR to Determine the Expression Levels of Inflammatory Mediators}

To examine whether M157-W suppresses P. gingivalis LPS-induced inflammatory responses, RAW 264.7 cells were co-treated with $P$. gingivalis LPS $(1 \mu \mathrm{g} / \mathrm{mL})$ and M157-W $(0,0.1,1,10$, or $100 \mu \mathrm{g} / \mathrm{mL})$ for $3 \mathrm{~h}$. Total RNA was then extracted from the cells using the TRIzol reagent (Invitrogen) according to the manufacturer's instructions. Subsequently, the total RNA was 
reverse transcribed to cDNA using random hexamers and reverse transcriptase (Promega). Samples were amplified by quantitative reverse-transcription PCR (qRT-PCR; Applied Biosystems) using the SYBR Green Real Time PCR master mix (Toyobo), according to the manufacturer's instructions. Expression levels of specific genes responsible for inflammatory responses, such as $I L 1 B, I L 6$, and inducible nitric oxide synthase (iNOS, encoded by NOS2) were amplified under the following PCR conditions: $95^{\circ} \mathrm{C}$ for $10 \mathrm{~s}$, followed by 40 cycles of $95^{\circ} \mathrm{C}$ for $5 \mathrm{~s}$ and $55^{\circ} \mathrm{C}$ for $31 \mathrm{~s}$. The primer sequences for $I L 1 B, I L 6$, and NOS2 were as follows: $I L 1 B$, forward, 5'-CTCACAAGCAGAGCACAAGC-3' and reverse, 5'-TCTTGGCCGAGGACTAAGGA-3'; IL6, forward, 5'-TCCTACCCCAATTTCCAATGCT-3' and reverse, 5'-TCTGACCACAGTGAGGAATGTC-3'; NOS2, forward, 5'-CATTGATCTCCGTGACAGCC-3' and reverse, 5'-CATGCTACTGGAGGTGGGTG-3'; $A C T B$, forward, 5'-TACAGCTTCACCACCACAGC-3' and reverse, 5'-GGAAAAGAGCCTCAGGGCAT-3' .

\section{qRT-PCR to Determine Expression Levels of S. mutans Biofilm-Associated Genes}

To investigate the inhibitory effect of M157-W on biofilm formation by $S$. mutans, gene expression levels of glucosyltransferases (gtf) were determined by qRT-PCR. Streptococcus mutans $\left(1 \times 10^{7} \mathrm{cfu} / \mathrm{mL}\right)$ was cultured with and without M157-W (0.001, 0.01, 0.1, or $1 \mathrm{mg} / \mathrm{mL}$ ) in brain heart infusion $(\mathbf{B H I})$ broth (Becton Dickinson) containing $0.05 \%$ sucrose at $37^{\circ} \mathrm{C}$ for $24 \mathrm{~h}$. For the control, S. mutans was also cultured with unfermented whey $(1 \mathrm{mg} / \mathrm{mL})$ under the same conditions. After centrifugation, bacterial pellets were resuspended in TRIzol reagent (Invitrogen) and transferred to tubes containing High Impact Zirconium Beads (Benchmark Scientific) and homogenized using a BeadBug microtube homogenizer (Benchmark Scientific) at $4^{\circ} \mathrm{C}$ for $100 \mathrm{~s}$ to lyse bacteria. Subsequently, total RNA was extracted from bacteria according to the manufacturer's instructions, and reverse transcribed into cDNA as described above. Amplifications of $g t f B$, gtfC, and $g t f D$ were conducted under the same PCR conditions as those described above. The relative expression levels of $g t f$ genes were analyzed using the $2^{-\Delta \Delta \mathrm{Ct}}$ method with normalization against the $16 \mathrm{~S}$ rRNA. The primer sequences of gtf genes were as follows: gtfB, forward, 5'-AGCAATGCAGCCAATCTACAAAT-3' and reverse, 5'-ACGAACTTTGCCGTTATTGTCA-3'; gtfC, forward, 5'-CTCAACCAACCGCCACTGTT-3' and reverse, 5'-GGTTAACGTCAAAATTAGCTGTATTAGC-3'; gtfD, forward, 5'-CACAGGCAAAAGCTGAATTACA-3' and reverse, 5'-GATGGCCGCTAAGTCAACAG-3'; 16S rRNA, forward, 5'-CCTACGGGAGGCAGCAGTAG-3' and reverse, 5'-CAACAGAGCTTTACGATCCGAAA-3'

\section{Determination of Cytokine and Nitric Oxide Production}

The RAW 264.7 cells $\left(5 \times 10^{5}\right.$ cells $\left./ \mathrm{mL}\right)$ or PDL cells $\left(2.5 \times 10^{5}\right.$ cells $\left./ \mathrm{mL}\right)$ were plated onto 48 -well culture plates and treated with various concentrations of M157-W $(0,0.1,1,10$, or $100 \mu \mathrm{g} / \mathrm{mL}$ or $100 \mu \mathrm{g} / \mathrm{mL}$, respectively) or unfermented whey $(100 \mu \mathrm{g} / \mathrm{mL})$ in the presence or absence of $P$. gingivalis LPS $(1 \mu \mathrm{g} / \mathrm{mL})$ for the indicated time periods. Subsequently, culture supernatants were collected and IL-1 $\beta$, IL-6, and IL-8 secretions were determined using a commercial ELISA kit (R\&D Systems) according to the manufacturer's instructions. To determine nitric oxide production, the culture supernatants were mixed with the same volume of the Griess reagent (1\% sulfanilamide, $0.1 \%$ naphthylethylenediamine dihydrochloride, and $2 \%$ phosphoric acid) and incubated at room temperature for $5 \mathrm{~min}$. Then, the optical density was measured at $540 \mathrm{~nm}$ using a microtiter plate reader (Allsheng) with $\mathrm{NaNO}_{2}$ as the standard.

\section{Western Blot Analysis for the Assessment of MAPK and NF-KB}

To examine whether mitogen-activated protein kinase (MAPK) and NF- $\kappa \mathrm{B}$ are involved in the inhibitory effect of M157-W on P. gingivalis LPS-induced inflammatory responses, RAW 264.7 cells $\left(5 \times 10^{5}\right.$ cells $/ \mathrm{mL})$ were treated with $\mathrm{M} 157-\mathrm{W}$ in the presence or absence of $P$. gingivalis LPS $(1 \mu \mathrm{g} / \mathrm{mL})$ for $30 \mathrm{~min}$. Cell lysates were obtained using a lysis buffer ( $1 \mathrm{M}$ HEPES, $1 M \mathrm{NaCl}, 1 \%$ IGEPAL-CA $630,0.75 \%$ sodium deoxycholate, $10 \%$ glycerol) containing proteinase inhibitors. Protein samples $(20 \mu \mathrm{g})$ were separated by SDS-PAGE on a $10 \%$ gel and then electro-transferred onto a PVDF membrane (Millipore). After blocking the membrane with $5 \%$ skim milk in Tris-buffered saline containing $0.1 \%$ Tween 20 , the membrane was incubated with specific primary antibodies against p38 kinase, phospho-p38 kinase, extracellular signal-regulated kinase (ERK), phospho-ERK, c-Jun-N-terminal kinase (JNK), phospho-JNK, or I $\kappa \mathrm{B} \alpha$ (Cell Signaling Technology) at $4^{\circ} \mathrm{C}$ overnight. The membrane was then washed with Tris-buffered saline containing $0.1 \%$ Tween 20 and incubated with horseradish peroxidaseconjugated anti-rabbit IgG antibody at room temperature for $1 \mathrm{~h}$. Immunoreactive bands were detected using an enhanced chemiluminescence reagent (Dyne Bio) and visualized using the $\mathrm{C}$-DiGit blot scanner (Li-Cor Bioscience). 


\section{Determination of S. mutans Biofilm}

The overnight culture of $S$. mutans was diluted to $1 \times$ $10^{7} \mathrm{cfu} / \mathrm{mL}$ in BHI broth containing $0.05 \%$ sucrose, and $100 \mu \mathrm{L}$ of $S$. mutans suspension was then transferred to 96-well microtiter plates in various concentrations of M157-W or unfermented whey $(0,0.001,0.01,0.1$ and $1 \mathrm{mg} / \mathrm{mL} ; 100 \mu \mathrm{L})$. To evaluate the inhibitory effect of M157-W on $S$. mutans biofilm, the bacteria were incubated at $37^{\circ} \mathrm{C}$ for $24 \mathrm{~h}$. Subsequently, the bacteria were gently washed with PBS to remove unattached bacteria and then stained with $0.1 \%$ crystal violet for $30 \mathrm{~min}$. After excess stain was removed by gently washing with PBS, the stained $S$. mutans biofilm was dissolved in $0.1 \%$ acetic acid and $95 \%$ ethanol and its absorbance was measured at $595 \mathrm{~nm}$ using a microtiter plate reader (Allsheng).

\section{Confocal Laser Scanning Microscopy for S. mutans Biofilm in the Presence of M157-W}

Streptococcus mutans $\left(1 \times 10^{7} \mathrm{cfu} / \mathrm{mL}\right)$ was cultured on a confocal dish (SPL Life Science) in BHI broth containing $0.05 \%$ sucrose to investigate biofilm formation with or without M157-W (1 mg/mL) at $37^{\circ} \mathrm{C}$ for $24 \mathrm{~h}$. Subsequently, the supernatants were discarded and the unattached bacteria were removed by gently washing with PBS. Streptococcus mutans biofilm was stained using the Live/Dead BacLight bacterial viability kit (Molecular Probes) according to the manufacturer's instructions. The stained biofilm was visualized using a confocal laser scanning microscope (Eclipse Ti-E, Nikon).

\section{Statistical Analysis}

Data presented in this study are expressed as mean \pm standard deviation of triplicate samples from 3 independent experiments. Statistical significance between groups was determined by either an unpaired 2-tailed $t$ test using GraphPad Prism 5 (GraphPad Software Inc.) or one-way ANOVA performed using the IBM SPSS Statistics 23 software (IBM Corp.).

\section{RESULTS AND DISCUSSION}

\section{Fermentation of Whey by E. faecalis M157 Suppresses $P$. gingivalis LPS-Induced Inflammatory Responses}

The M157-W significantly $(P<0.05)$ inhibited the mRNA expression of $P$. gingivalis LPS-induced $I L 1 B$ (Figure 1A), IL6 (Figure 1C), and NOS2 (Figure 1E) in a dose-dependent manner. The highest concentration of M157-W $(100 \mu \mathrm{g} / \mathrm{mL})$ most effectively inhibited the mRNA expression of $I L 1 B, I L 6$, and NOS2 by approximately 80,32 , and $57 \%$, respectively. Therefore, 100 $\mu \mathrm{g} / \mathrm{mL}$ of M157-W was used for further experiments. Treatment of RAW 264.7 cells with $P$. gingivalis LPS in the presence or absence of M157-W $(100 \mu \mathrm{g} / \mathrm{mL})$ for various time periods $(1,3,6,12$, and $24 \mathrm{~h})$ revealed that M157-W significantly $(P<0.05)$ inhibited the mRNA expression of $I L 1 B$ (Figure 1B), IL6 (Figure 1D), and NOS2 (Figure 1F) with 3 and $6 \mathrm{~h}$ of incubation. However, M157-W did not inhibit the mRNA expression of $I L 1 B, I L 6$, and NOS2 after 12 and $24 \mathrm{~h}$ of incubation, suggesting that M157-W effectively inhibits expression of genes responsible for inflammatory responses at early time points in RAW 264.7 cells. The inhibition of inflammatory responses by M157-W was confirmed at the protein level by treating RAW 264.7 cells with $P$. gingivalis LPS in either the presence or absence of M157-W and determining the amounts of IL-1 $\beta$, IL-6, and NO production. Consistent with the results of mRNA expression, the secretion of IL-1 $\beta$ and IL-6 was significantly $(P<0.05)$ reduced by M157-W treatment (Figures $2 \mathrm{~A}$ and $2 \mathrm{C}$, respectively). The NO production was dose-dependently inhibited by M157-W treatment (Figure 2E). The inhibition was temporally investigated by treating RAW 264.7 cells with $P$. gingivalis LPS or M157-W (100 $\mu \mathrm{g} / \mathrm{mL})$, or both, for 1,3 , 6,12 , and $24 \mathrm{~h}$. The secretion of IL- $1 \beta$ was significantly $(P<0.05)$ inhibited in the presence of M157-W at 12 and $24 \mathrm{~h}$ (Figure 2B), whereas that of IL-6 was significantly $(P<0.05)$ reduced at $24 \mathrm{~h}$, but not at 12 h (Figure 2D). Nitric oxide production also decreased at 12 and $24 \mathrm{~h}$ in the presence of M157-W (Figure 2F). These results suggest that M157-W most effectively reduced the protein levels of IL-1 $\beta$, IL- 6 , and NO at $24 \mathrm{~h}$ of incubation. During an inflammatory process, several inflammatory mediators are generated, among which IL-1 $\beta$ has been demonstrated to be one of the most important inflammatory cytokines, produced by macrophages, that are stimulated by LPS and lead to cell and tissue damage (Won et al., 2006). Interleukin-6 has the multiple effects on the immune system, such as hematopoiesis (Van Snick, 1990). Synthesized by iNOS, NO is a common molecule that is crucially involved in the pathogenesis of LPS-induced inflammation (Won et al., 2006). The excessive production of IL-1 $\beta$ can lead to the acceleration of periodontal tissues (Cheng et al., 2020). In addition, IL-1 $\beta$ and IL-6 induce matrixmetalloproteinase-1 expression, resulting in periodontal tissue destruction (Sawada et al., 2013). Nitric oxide mediates the pathological effects of bacterial LPS and inflammatory cytokines, such as IL-1 $\beta$, indicating that NO may be involved in the development of periodontitis (Wang et al., 2019). Our findings showed that 
M157-W effectively suppresses inflammatory mediators, thereby relieving inflammation. To evaluate the whey fermented by E. faecalis M157, the antiinflammatory activity of unfermented whey was also examined. As shown in Figure 3, unfermented whey appears to inhibit the mRNA expression of IL1B,IL6, and NOS2 in RAW 264.7 cells stimulated with $P$. gingivalis LPS. However, the inhibitory effects of unfermented whey $(12,23$, and $22 \%$ inhibition, respectively) at $100 \mu \mathrm{g} / \mathrm{mL}$ on $I L 1 B$ (Figure $3 \mathrm{~A}$ ), IL6 (Figure 3B), and NOS2 (Fig-
A

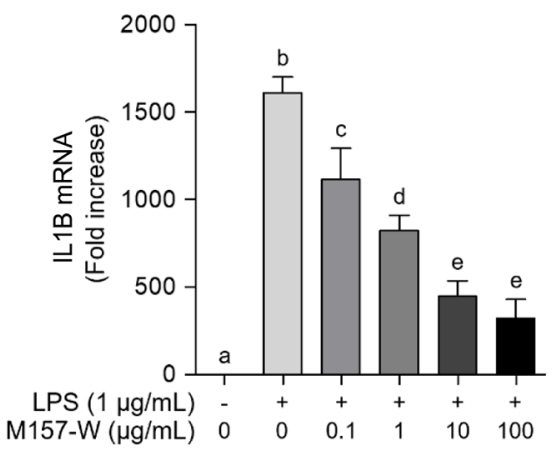

C

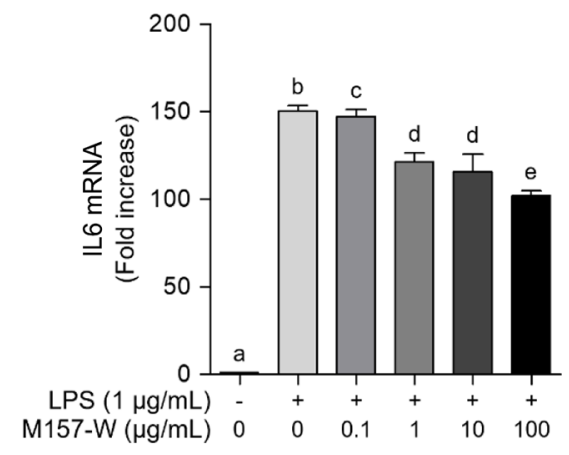

E

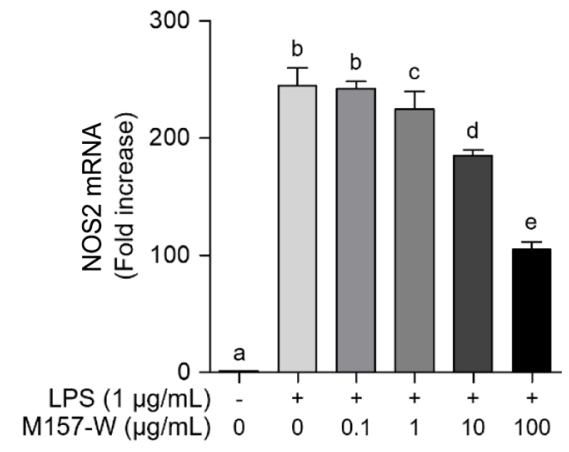

B

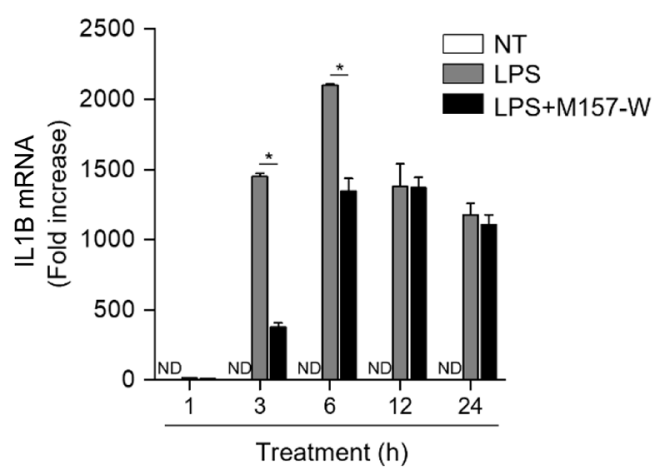

D

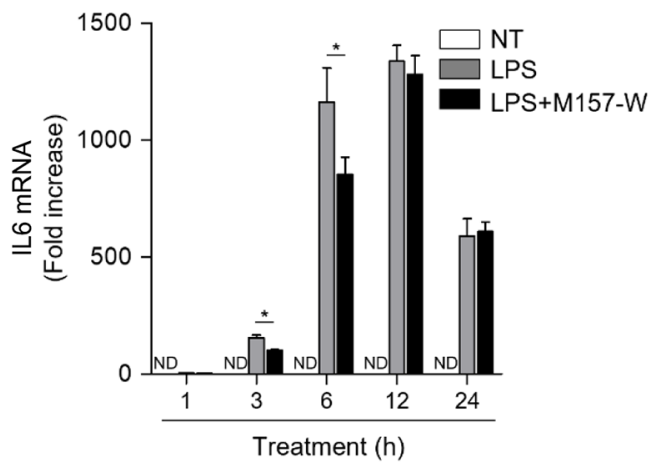

$\mathbf{F}$

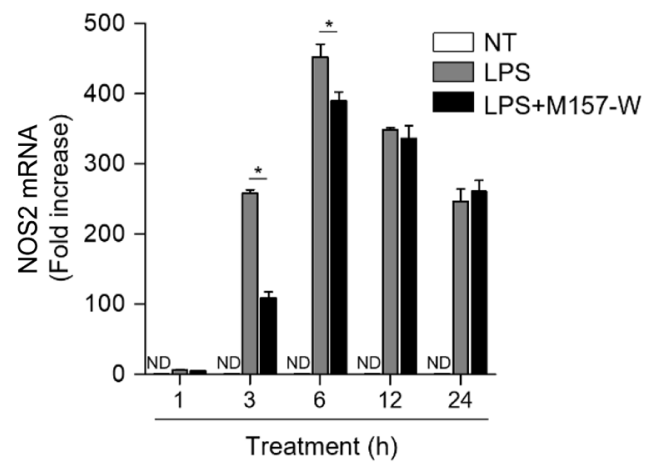

Figure 1. Inhibitory effects of whey fermented by Enterococcus faecalis M157 (M157-W) on the mRNA expression levels of Porphyromonas gingivalis LPS-induced proinflammatory mediators in RAW 264.7 cells. The RAW 264.7 cells were co-incubated with $P$. gingivalis LPS (1 $\mu \mathrm{g} /$ $\mathrm{mL}$ ) and various concentrations of M157-W. After $3 \mathrm{~h}$ of incubation, mRNA expression of IL1B (A), IL6 (C), and inducible nitric oxide synthase (NOS2; E) was determined using quantitative reverse-transcription PCR (qRT-PCR). The control was the treatment with P. gingivalis LPS only $(1 \mu \mathrm{g} / \mathrm{mL})$. After RAW 264.7 cells were co-incubated with $P$. gingivalis $\mathrm{LPS}(1 \mu \mathrm{g} / \mathrm{mL})$ and M157-W $(100 \mu \mathrm{g} / \mathrm{mL})$ for $1,3,6$, 12 , and $24 \mathrm{~h}$, mRNA expression levels of $I L 1 B(\mathrm{~B}), I L 6$ (D), and NOS2 (F) were determined using qRT-PCR. The control was the treatment with P. gingivalis LPS only $(1 \mu \mathrm{g} / \mathrm{mL})$ at each time point. NT and ND denote not treated and not detected, respectively. Significance between groups was determined by one-way ANOVA (A, C, and $\mathrm{E}$ ) and 2-tailed $t$-test $(\mathrm{B}, \mathrm{D}$, and $\mathrm{F})$. The results are presented as mean \pm standard deviation. Different lowercase letters $(\mathrm{a}-\mathrm{e})$ or an asterisk indicate a significant difference with $P<0.05$. 
ure 3C) mRNA expression were much lower than those of M157-W. Moreover, unfermented whey $(100 \mu \mathrm{g} / \mathrm{mL})$ slightly inhibited IL-1 $\beta$ and NO production (Figure
$3 \mathrm{D}$ and $3 \mathrm{~F}$, respectively), whereas IL-6 production was not inhibited by the treatment with unfermented whey (Figure 3E). Therefore, fermented whey exhibits more
A

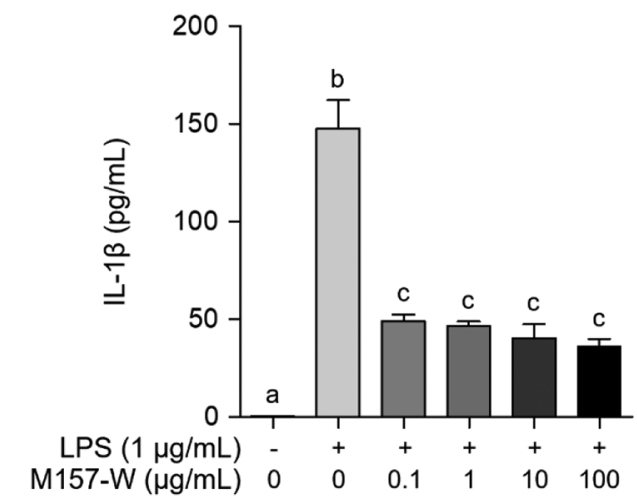

C

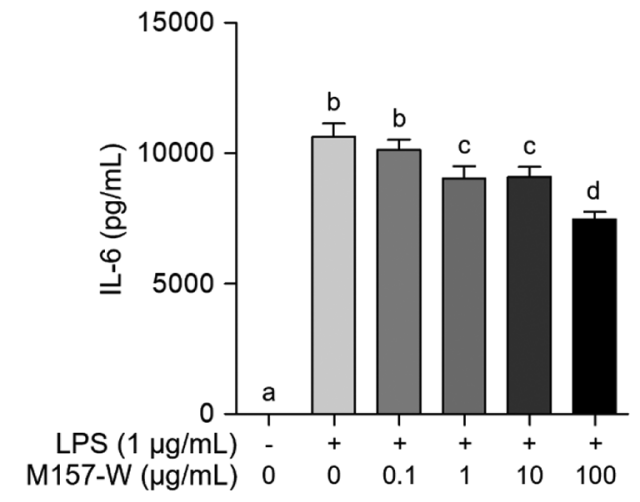

E

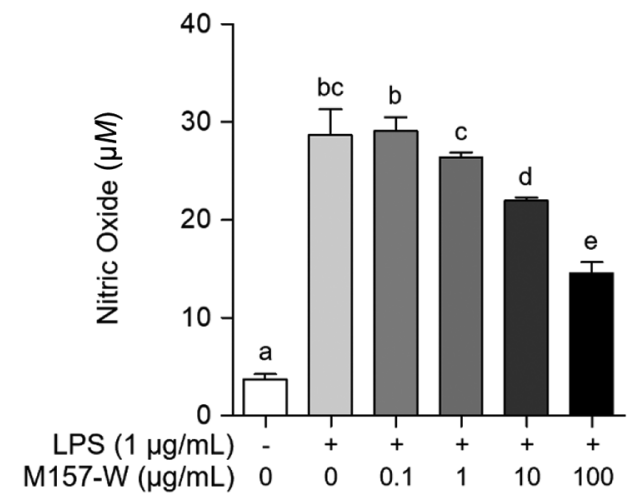

B

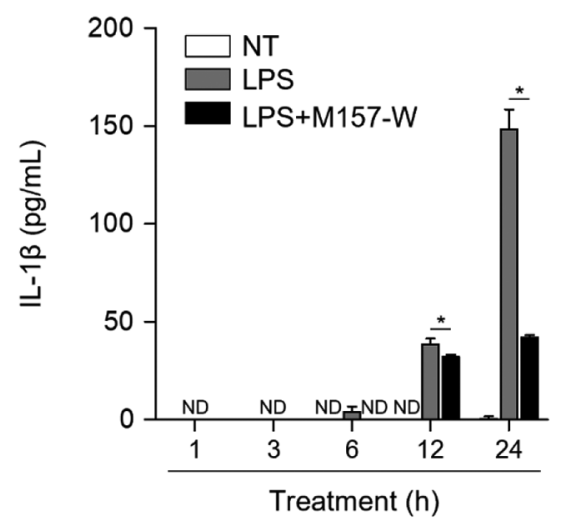

D

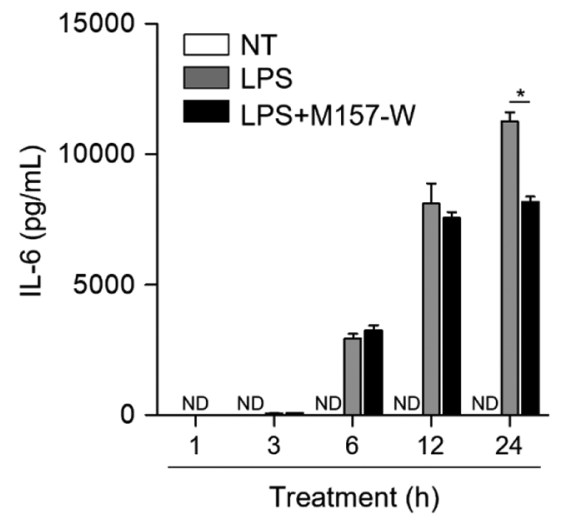

$\mathbf{F}$

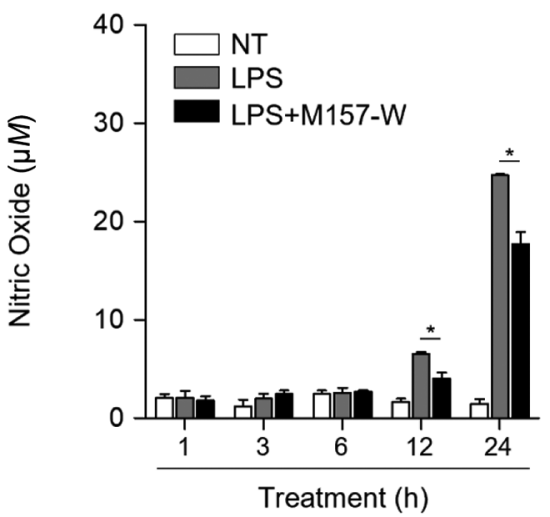

Figure 2. Inhibitory effects of whey fermented by Enterococcus faecalis M157 (M157-W) on the production of Porphyromonas gingivalis LPS-induced proinflammatory mediators in RAW 264.7 cells. RAW 264.7 cells were co-incubated with $P$. gingivalis $\mathrm{LPS}(1 \mu \mathrm{g} / \mathrm{mL})$ and various concentrations of M157-W. After $24 \mathrm{~h}$ of incubation, protein levels of IL-13 (A) and IL-6 (C) were determined using ELISA, and NO production (E) was measured using the Griess reagent. The control was the treatment with $P$. gingivalis LPS only $(1 \mu \mathrm{g} / \mathrm{mL})$. After RAW 264.7 cells were co-incubated with $P$. gingivalis LPS $(1 \mu \mathrm{g} / \mathrm{mL})$ and M157-W $(100 \mu \mathrm{g} / \mathrm{mL})$ for 1, 3, 6, 12, and $24 \mathrm{~h}$, protein levels of IL-13 (B) and IL-6 (D) were determined using ELISA, and NO production (F) was measured using the Griess reagent. The control was the treatment with P. gingivalis LPS only $(1 \mu \mathrm{g} / \mathrm{mL})$ at each time point. NT and ND denote not treated and not detected, respectively. Significance between groups was determined by one-way ANOVA (A, C, and E) and 2-tailed $t$-test (B, D, and F). The results are presented as mean \pm standard deviation. Different lowercase letters $(\mathrm{a}-\mathrm{e})$ and an asterisk indicate a significant difference with $P<0.05$. 
effective antiinflammatory activities against $P$. gingivalis LPS. In fact, peptides derived from whey have been shown to exhibit antiinflammatory potential. Two purified peptides, Asp-Tyr-Lys-Lys-Tyr and Asp-GlnTrp-Leu, have been reported to exhibit strong inhibitory effects on the mRNA expression of $I L 1 B$, tumor necrosis factor- $\alpha$, and cyclooxygenase-2 in RAW 264.7 cells stimulated by Escherichia coli O111:B4 LPS (Ma et al., 2016). It has been established that $E$. coli LPS exclusively activates toll-like receptor (TLR) 4 on the cell surface, leading to inflammatory responses (Netea et al., 2002). In contrast, $P$. gingivalis LPS predominantly activates TLR2 and poorly activates TLR4 (Martin et al., 2001), suggesting that inflammatory consequences may be different by the exposure to $E$. coli LPS and $P$. gingivalis LPS. Furthermore, unlike the previous study by Ma et al. (2016) that identified 2 peptides with an- tiinflammatory potential derived from whey, our study has not identified specific peptides responsible for the inhibition of $P$. gingivalis LPS-induced inflammatory responses. However, it can be deduced that peptides released from whey during fermentation by E. faecalis M157 could be associated with the inhibition of $P$. gingivalis LPS-induced inflammatory responses.

\section{Fermentation of Whey by E. faecalis M157 Suppresses MAPK Phosphorylation and $N F-K B$ Activation}

As shown in Figure 4A, P. gingivalis LPS induced the phosphorylation of MAPK such as p38, ERK, and JNK in RAW 264.7 cells; in contrast, M157-W treatment inhibited the phosphorylation of p38, ERK, and JNK, suggesting that $P$. gingivalis LPS-mediated inflamma-
A

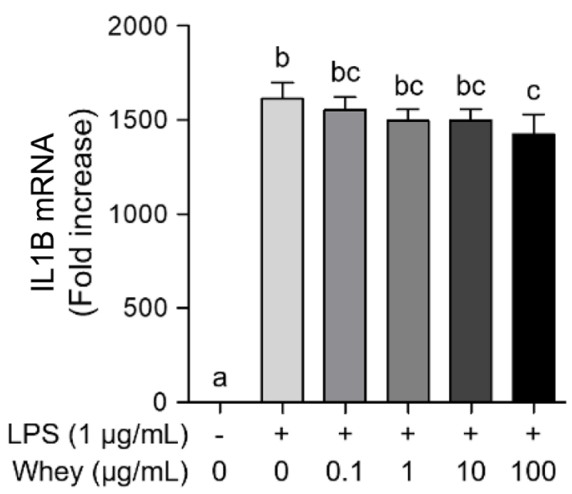

D

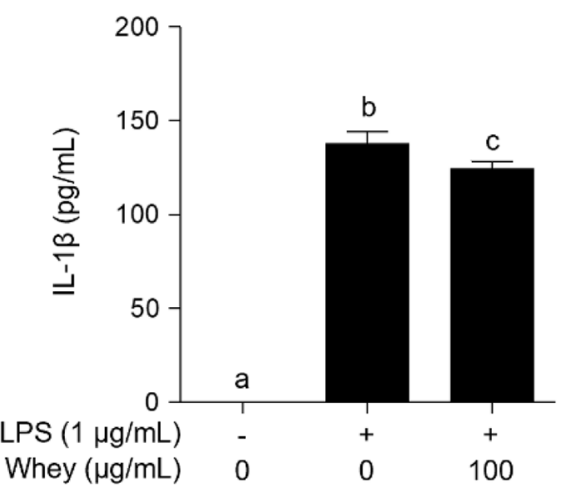

B

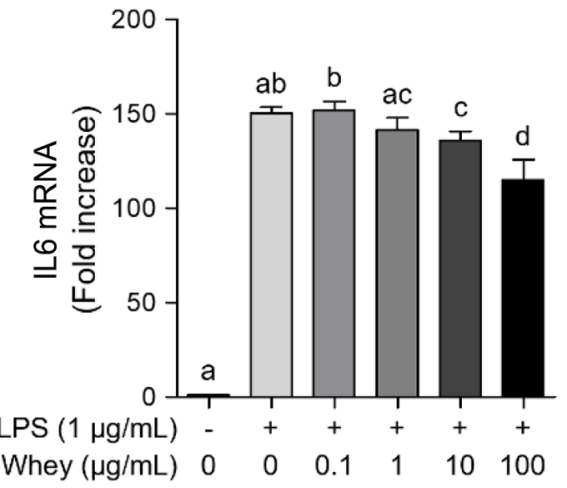

E

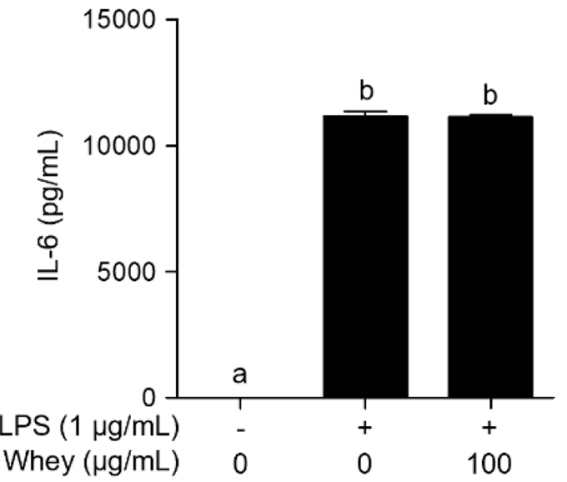

C

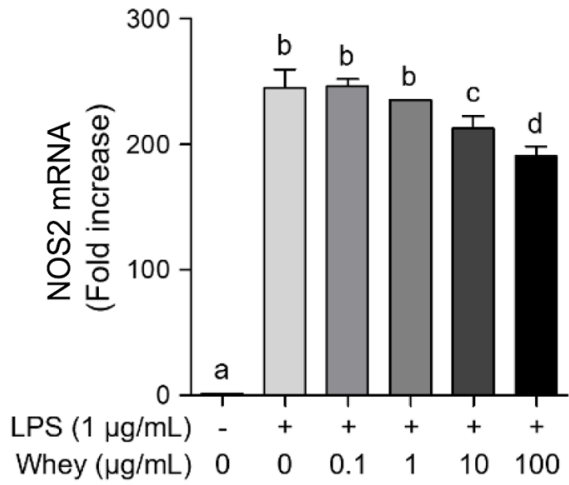

F

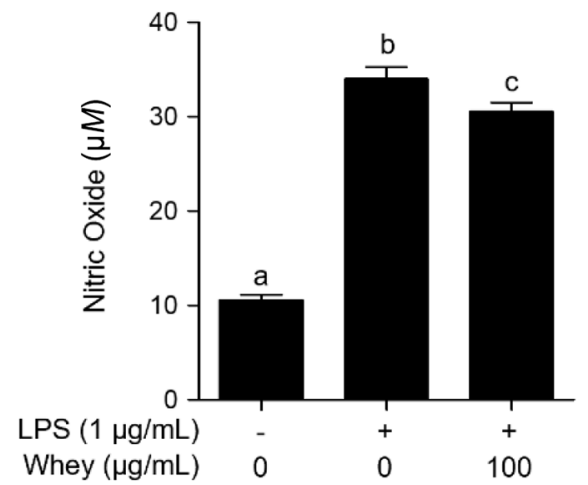

Figure 3. Effects of unfermented whey on the inhibition of Porphyromonas gingivalis LPS-induced inflammatory mediators in RAW 264.7 cells. The RAW 264.7 cells were co-incubated with $P$. gingivalis LPS $(1 \mu \mathrm{g} / \mathrm{mL})$ with various concentrations of unfermented whey for 3 h. mRNA expression levels of $I L 1 B(\mathrm{~A}), I L 6(\mathrm{~B})$, and inducible nitric oxide synthase (NOS2; C) were determined using quantitative reverse-transcription PCR (qRT-PCR). After RAW 264.7 cells were co-incubated with $P$. gingivalis LPS $(1 \mu \mathrm{g} / \mathrm{mL})$ and unfermented whey (100 $\mu$ g/mL) for $24 \mathrm{~h}$, protein levels of IL-1 $\beta$ (D) and IL-6 (E) were determined using ELISA, and NO production (F) was measured using the Griess reagent. The control was the treatment with $P$. gingivalis LPS only $(1 \mu \mathrm{g} / \mathrm{mL})$. Significance between groups was determined by one-way ANOVA. The results are presented as mean \pm standard deviation. Different lowercase letters $(\mathrm{a}-\mathrm{d})$ indicate a significant difference with $P<0.05$. 
tory responses are reduced by decreasing the phosphorylation of MAPK. Furthermore, M157-W restored $P$. gingivalis LPS-induced $\mathrm{I} \kappa \mathrm{B} \alpha$ degradation in a dosedependent manner (Figure 4B). These results indicate that M157-W suppresses $P$. gingivalis LPS-induced activation of MAPK and NF- $\kappa B$, thereby attenuating the inflammatory responses in RAW 264.7 cells. The stimulation of cells with $P$. gingivalis LPS increased the production of proinflammatory cytokines, such as IL$1 \beta$ and IL-6, through the upregulation of MAPK and

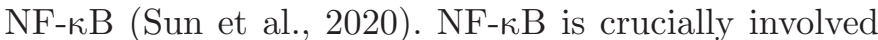
in inflammatory reactions; the inhibitors of NF- $\kappa \mathrm{B}$, including $\mathrm{I} \kappa \mathrm{B} \alpha$, are important in downregulating NF$\kappa \mathrm{B}$ activation (Wang et al., 2020). Several studies have confirmed that MAPK and NF- $\mathrm{BB}$ signaling pathways are involved in periodontitis (Liang et al., 2014; Kim et al., 2018). Ginsenoside Rb3 has been reported to attenuate periodontitis by downregulating MAPK and NF- $\kappa$ B signaling pathways (Sun et al., 2020). Moreover, panduratin A isolated from Boesenbergia pandurata has

A
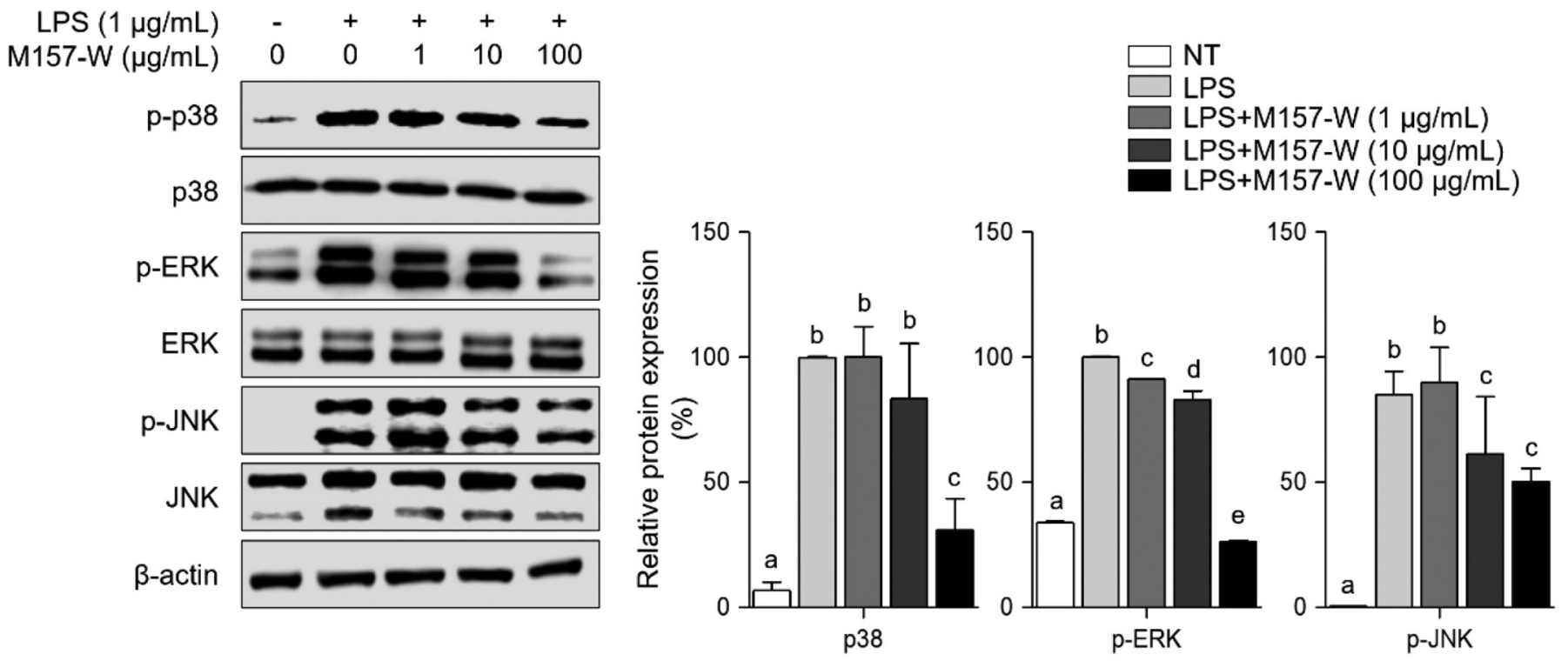

B
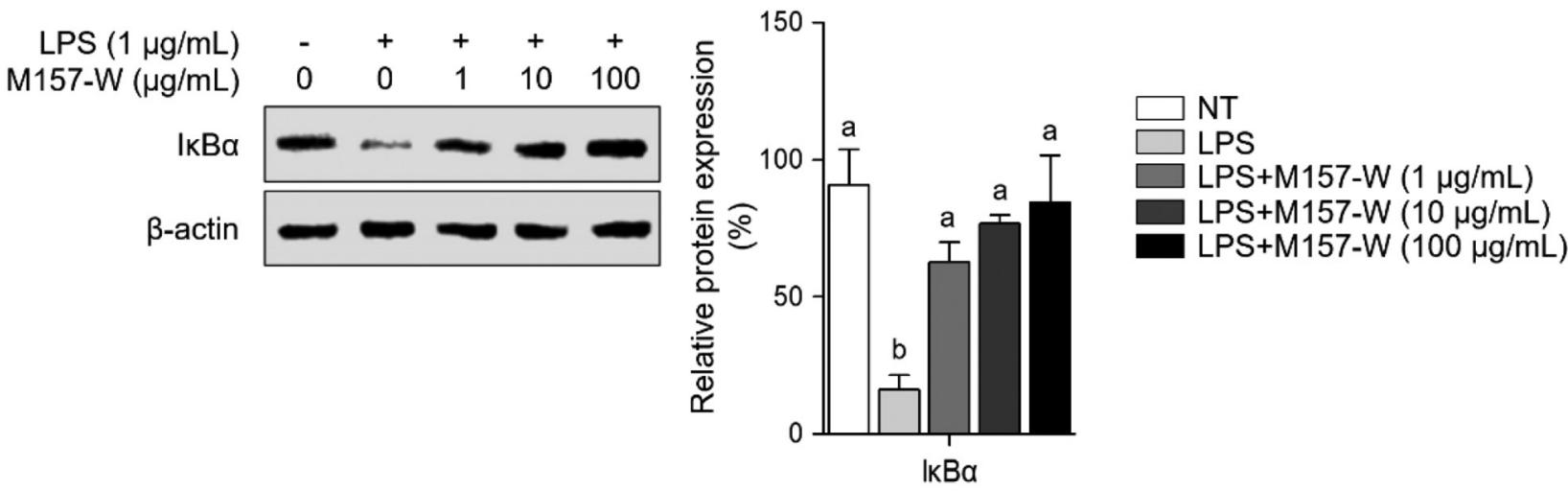

Figure 4. Inhibitory effects of whey fermented by Enterococcus faecalis M157 (M157-W) on mitogen-activated protein kinase (MAPK) phos-

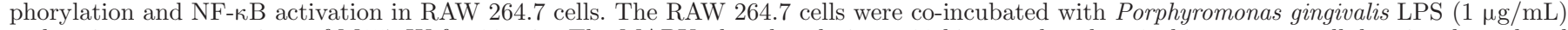
and various concentrations of M157-W for 30 min. The MAPK phosphorylation, p38 kinase, phospho-p38 kinase, extracellular signal-regulated

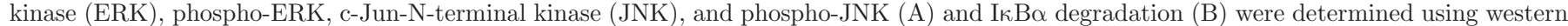
blot analysis. The control was the treatment with $P$. gingivalis LPS only $(1 \mu \mathrm{g} / \mathrm{mL})$. The relative expression levels of each MAPK and I $\kappa \alpha$ are represented as mean \pm standard deviation obtained from 3 independent experiments. Significance between groups was determined by one-way ANOVA. NT denotes not treated. The results are presented as mean \pm standard deviation. Different lowercase letters (a-e) indicate a significant difference with $P<0.05$ 
been shown to suppress MAPK signaling pathways in periodontitis-associated inflammatory responses (Kim et al., 2018). Our study also suggests that M157-W can demonstrate an antagonistic effect on $P$. gingivalis LPS-induced inflammatory responses by inhibiting MAPK and NF- $\kappa$ B signaling pathways.

\section{Whey Fermented by E. faecalis M157 Inhibits $P$. gingivalis LPS-Induced Inflammatory Responses in PDL Cells}

To evaluate the inhibition of $P$. gingivalis LPS-induced inflammatory responses in PDL cells by M157-W, the cells were co-treated with $\mathrm{M} 157-\mathrm{W}$ and $P$. gingivalis LPS, and the levels of IL-1 $\beta$, IL-6, and IL- 8 secretion were measured. As shown in Figure 5A, $P$. gingivalis LPS significantly $(P<0.05)$ induced IL-1 $\beta$ secretion, which was moderately decreased in the presence of M157-W. However, unfermented whey failed to inhibit P. gingivalis LPS-induced IL-1 $\beta$ secretion. Porphyromonas gingivalis LPS induced IL-6 secretion, whereas M157-W and unfermented whey significantly $(P<$ 0.05 ) inhibited IL-6 secretion (Figure 5B). Moreover, $P$. gingivalis LPS induced IL-8 secretion in PDL cells, whereas M157-W treatment significantly $(P<0.05)$ inhibited this increased IL-8 secretion, unlike unfermented whey (Figure 5C). These results indicate that M157-W partially attenuates inflammatory responses in PDL cells. In addition to $P$. gingivalis, several bacteria including Streptococcus gordonii, a particularly harmful pathogen, are involved in the development of periodontitis. Kim et al. (2017) showed that S. gordo- nii lipoproteins increase IL-8 production in PDL cells, which crucially contributes to inflammatory periodontitis. Our results revealed that $P$. gingivalis LPS-induced proinflammatory mediators were downregulated by M157-W, suggesting that M157-W can decrease inflammatory periodontitis by partially inhibiting the secretion of IL-1 $\beta$ and IL- 8 in human PDL cells.

\section{Whey Fermented by E. faecalis M157 Suppresses S. mutans Biofilm}

The effect of M157-W on the biofilm formation by $S$. mutans was investigated using crystal violet staining. Our results showed that M157-W dose-dependently inhibits S. mutans biofilm formation (Figure 6A). In contrast, unfermented whey did not inhibit $S$. mutans biofilm (Figure 6B). As shown in Figure 6C, confocal laser scanning microscopy confirmed that $S$. mutans biofilm was less dense in the presence of M157-W than in its absence. A potential probiotic strain, L. salivarius, reduces the biofilm formation by $S$. mutans (Wu et al., 2015). More recently, L. plantarum showed an inhibitory effect on the biofilm formation and the growth of S. mutans (Zhang et al., 2020). Although the previous studies have reported that probiotics exhibit antibiofilm activity against $S$. mutans, whey fermentation by lactic acid bacteria has not elucidated the antibiofilm activity against $S$. mutans. Our results suggested that M157-W inhibits $S$. mutans biofilm. In addition, the genes gtfB, $g t f C$, and $g t f D$ are associated with EPS synthesis (Koo et al., 2010). For instance, deleting gtfB and $g t f C$ in $S$. mutans has been shown to result in the disruption of

A

B

C
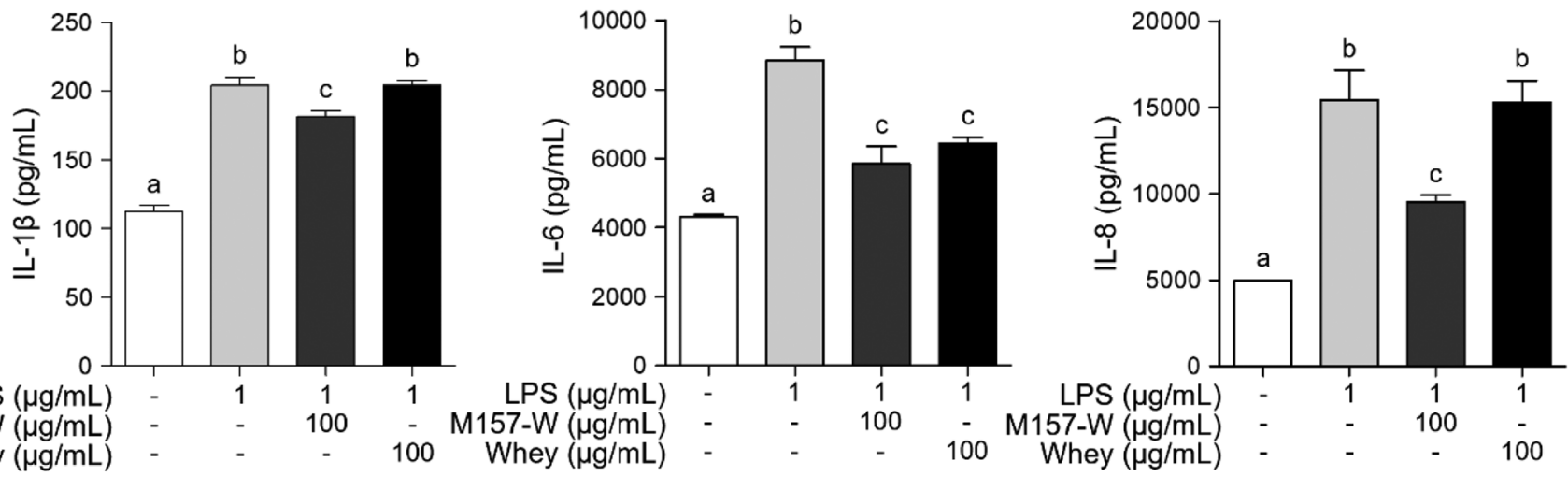

Figure 5. Effects of whey fermented by Enterococcus faecalis M157 (M157-W) on Porphyromonas gingivalis LPS-induced proinflammatory cytokines in PDL cells. PDL cells were treated with either M157-W (100 $\mathrm{gg} / \mathrm{mL})$ or unfermented whey (100 $\mu \mathrm{g} / \mathrm{mL})$ in the presence of $P$. gingivalis LPS $(1 \mu \mathrm{g} / \mathrm{mL})$ for $24 \mathrm{~h}$. The protein levels of IL-1 $\beta$ (A), IL-6 (B), and IL-8 (C) were determined using ELISA. The control was the treatment with $P$. gingivalis LPS only $(1 \mu \mathrm{g} / \mathrm{mL})$. Significance between groups was determined by one-way ANOVA. The results are presented as mean \pm standard deviation. Different lowercase letters $(\mathrm{a}-\mathrm{c})$ indicate a significant difference with $P<0.05$. 
microcolony and biofilm formation (Fears et al., 2015). Therefore, gtf genes are essential for the development of $S$. mutans biofilm. Our results showed that M157W dose-dependently inhibits the expression levels of gtfB (Figure 7A), gtfC (Figure 7B), and gtfD (Figure $7 \mathrm{C})$. In contrast, unfermented whey $(1 \mathrm{mg} / \mathrm{mL})$ did not inhibit the expression levels of $g t f B$ (Figure 7D), gtfC (Figure 7E), and gtfD (Figure 7F). Several studies have shown that antibiofilm compounds prevent $S$. mutans biofilm by regulating the expression levels of biofilm- associated genes including gtf genes (Koo et al., 2006; Salles Branco-de-Almeida et al., 2011; Subramenium et al., 2015). Interpreted together with previous results, our results indicate that M157-W suppresses $S$. mutans biofilm formation by downregulating $g t f$ genes.

\section{CONCLUSIONS}

In this study, we demonstrated that M157-W effectively inhibits $P$. gingivalis LPS-induced inflammatory
A

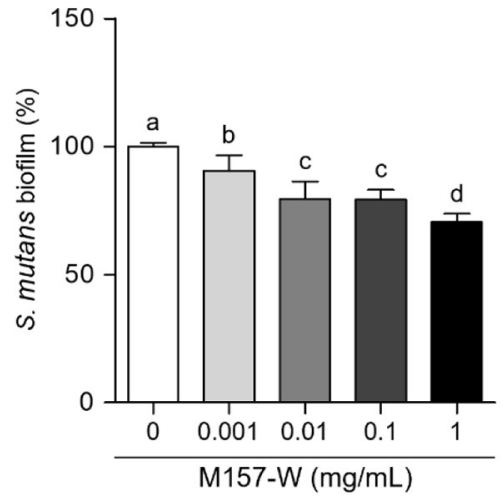

B

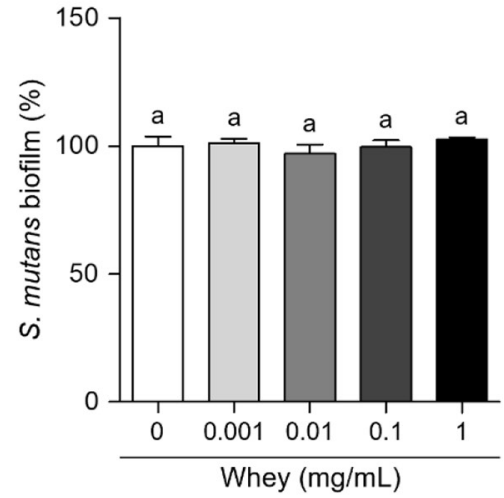

C
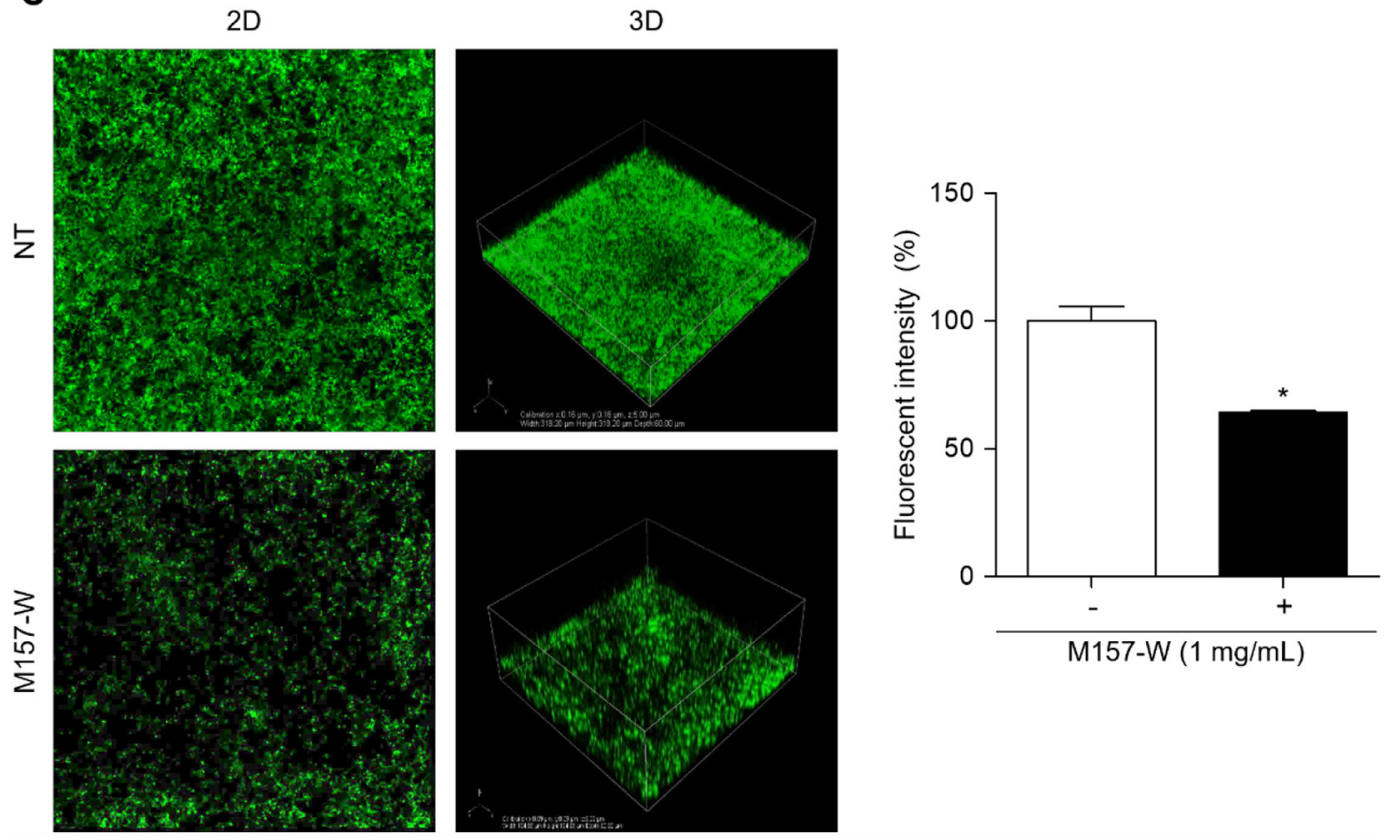

Figure 6. Antibiofilm activity of whey fermented by Enterococcus faecalis M157 (M157-W) against Streptococcus mutans. Streptococcus mutans was incubated with either different concentrations of M157-W (A) or unfermented whey (B; 0, 0.001, 0.01, 0.1, and 1 mg/mL) in 96-well culture plates for $24 \mathrm{~h}$. Streptococcus mutans biofilm was examined using crystal violet staining. The control was the treatment without M157-W or unfermented whey. Significance between groups were determined by one-way ANOVA. (C) S. mutans biofilm in either the presence or absence of M157-W (1 mg/mL) was assessed using confocal laser scanning microscopy. Images displayed were selected from 1 of 3 similar results. The fluorescent intensity of images from S. mutans biofilm treated without M157-W (1 mg/mL) was assigned to $100 \%$. Significance between groups was determined by 2 -tailed $t$-test. NT denotes not treated. The results are presented as mean \pm standard deviation. Different lowercase letters (a-d) and an asterisk indicate a significant difference with $P<0.05$ 
A

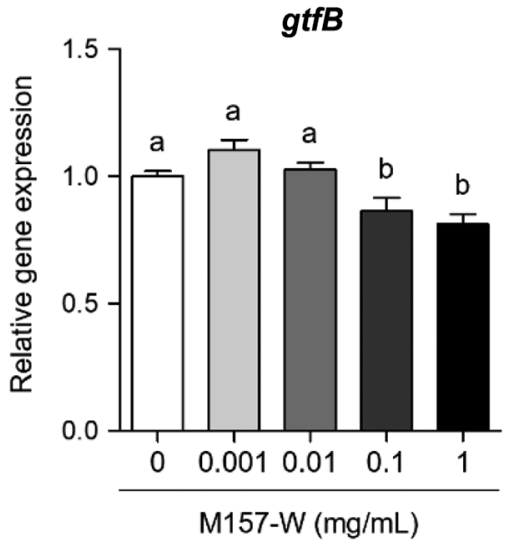

D

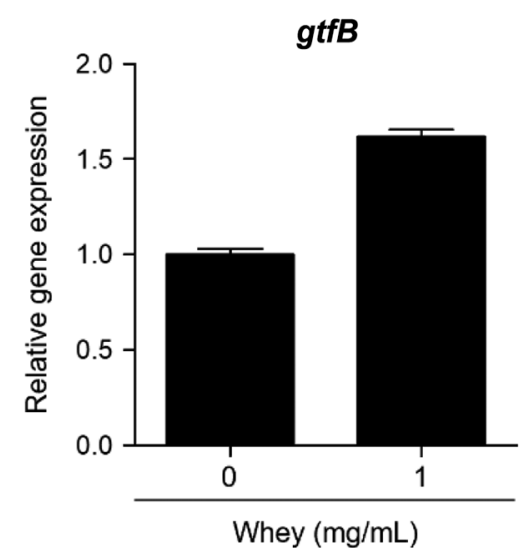

B

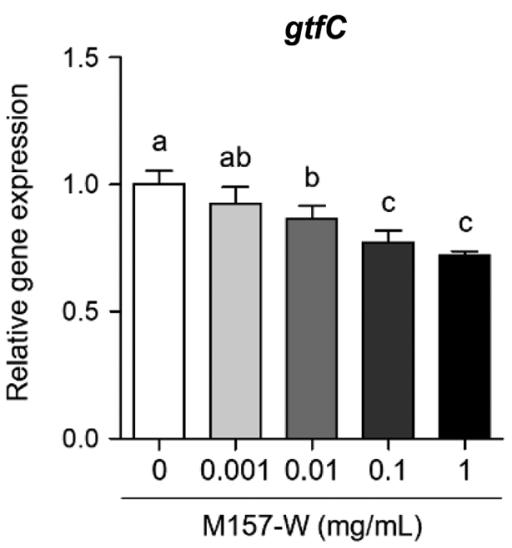

E

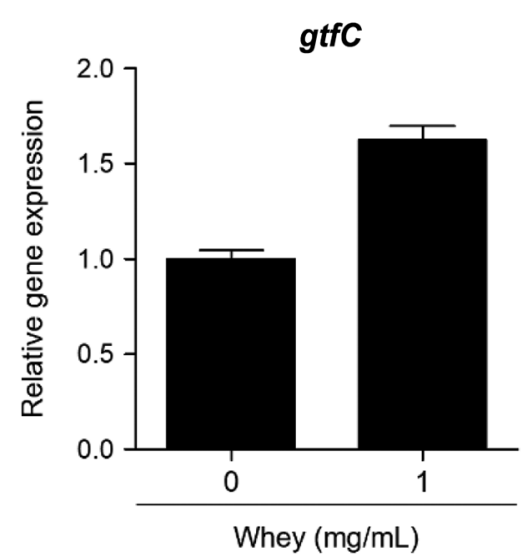

C

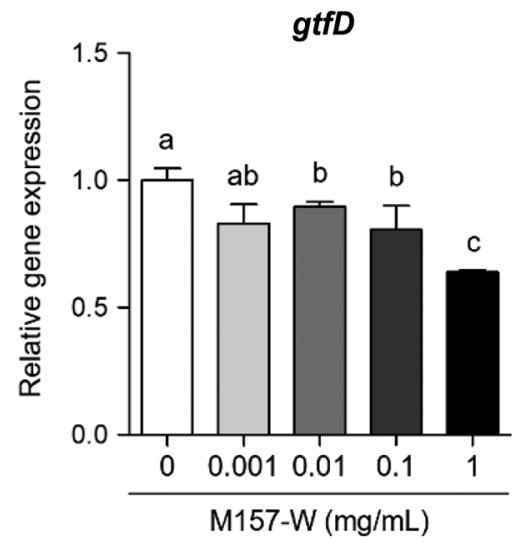

F

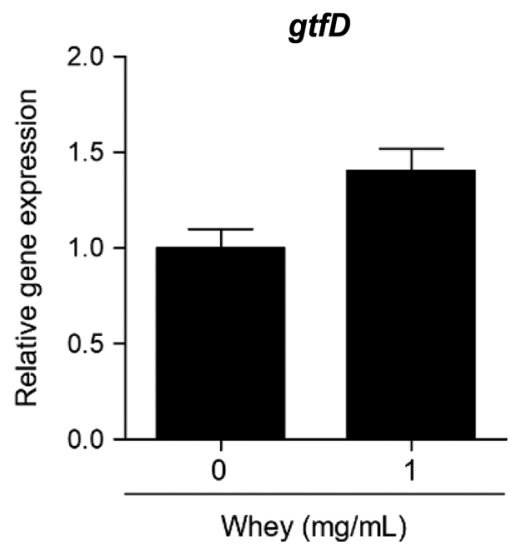

Figure 7. Effects of whey fermented by Enterococcus faecalis M157 on the expression levels of genes responsible for Streptococcus mutans

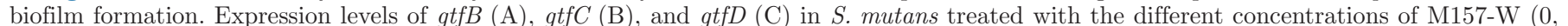

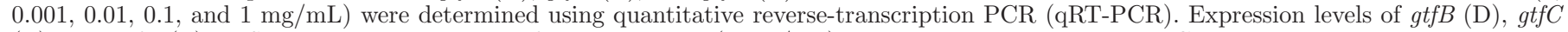
(E), and gtfD (F) in $S$. mutans treated with unfermented whey $(1 \mathrm{mg} / \mathrm{mL})$ were determined using qRT-PCR. The control was the treatment

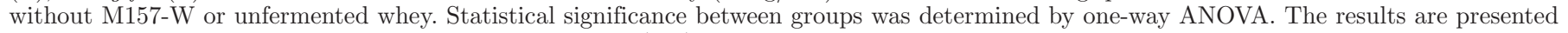
as mean \pm standard deviation. Different lowercase letters (a-e) indicate a significant difference with $P<0.05$.

responses. In addition, M157-W moderately suppressed S. mutans biofilm formation that may be associated with the downregulation of genes responsible for EPS synthesis. Although the antiinflammatory effects of whey have been reported previously, the antiinflammatory and antibiofilm activities of fermented whey against oral pathogenic bacteria were demonstrated here for the first time. Although further studies are required to identify specific compounds in fermented whey that are involved in these antiinflammatory and antibiofilm activities, this study highlights the promising preventive and therapeutic potential of M157-W in the treatment of periodontitis and dental caries.

\section{ACKNOWLEDGMENTS}

This work was supported by the Korea Institute of Planning and Evaluation for Technology in Food, Ag- riculture, Forestry and Fisheries (IPET) through the High Value-added Food Technology Development Program, funded by the Ministry of Agriculture, Food and Rural Affairs (MAFRA; 318091-03-2-HD050; Sejong, Korea). The authors have not stated any conflicts of interest.

\section{REFERENCES}

Albuquerque-Souza, E., D. Balzarini, E. S. Ando-Suguimoto, K. H. Ishikawa, M. R. Simionato, M. Holzhausen, and M. P. Mayer. 2019. Probiotics alter the immune response of gingival epithelia cells challenged by Porphyromonas gingivalis. J. Periodontal Res. 54:115-127. https://doi.org/10.1111/jre.12608.

Bowen, W. H., and H. Koo. 2011. Biology of Streptococcus mutansderived glucosyltransferases: Role in extracellular matrix formation of cariogenic biofilms. Caries Res. 45:69-86. https://doi.org/ $10.1159 / 000324598$.

Cheng, R., Z. Wu, M. Li, M. Shao, and T. Hu. 2020. Interleukin1 beta is a potential therapeutic target for periodontitis: A narrative review. Int. J. Oral Sci. 12:2. https://doi.org/10.1038/s41368 $-019-0068-8$. 
Fears, K. P., M. Gonzalez-Begne, C. T. Love, D. E. Day, and H. Koo. 2015. Surface-induced changes in the conformation and glucan production of glucosyltransferase adsorbed on saliva-coated hydroxyapatite. Langmuir 31:4654-4662. https://doi.org/10.1021/ la504461h.

Garcia-Cano, I., D. Rocha-Mendoza, J. Ortega-Anaya, K. Wang, E. Kosmerl, and R. Jimenez-Flores. 2019. Lactic acid bacteria isolated from dairy products as potential producers of lipolytic, proteolytic and antibacterial proteins. Appl. Microbiol. Biotechnol. 103:5243-5257. https://doi.org/10.1007/s00253-019-09844-6.

Hanchi, H., R. Hammami, R. Kourda, J. B. Hamida, and I. Fliss. 2014. Bacteriocinogenic properties and in vitro probiotic potential of enterococci from Tunisian dairy products. Arch. Microbiol. 196:331-344. https://doi.org/10.1007/s00203-014-0978-y.

Hanchi, H., W. Mottawea, K. Sebei, and R. Hammami. 2018. The genus Enterococcus: Between probiotic potential and safety concernsAn update. Front. Microbiol. 9:1791. https://doi.org/10.3389/ fmicb.2018.01791.

Ishikawa, K. H., D. Mita, D. Kawamoto, J. R. Nicoli, E. AlbuquerqueSouza, M. R. Lorenzetti Simionato, and M. P. A. Mayer. 2020. Probiotics alter biofilm formation and the transcription of Porphyromonas gingivalis virulence-associated genes. J. Oral Microbiol. 12:1805553. https://doi.org/10.1080/20002297.2020.1805553.

Kechagia, M., D. Basoulis, S. Konstantopoulou, D. Dimitriadi, K. Gyftopoulou, N. Skarmoutsou, and E. M. Fakiri. 2013. Health benefits of probiotics: A review. ISRN Nutr. 2013:481651. https:// doi.org/10.5402/2013/481651.

Kim, A. R., K. B. Ahn, H. Y. Kim, H. S. Seo, K. Y. Kum, C. H. Yun, and S. H. Han. 2017. Streptococcus gordonii lipoproteins induce IL-8 in human periodontal ligament cells. Mol. Immunol. 91:218224. https://doi.org/10.1016/j.molimm.2017.09.009.

Kim, H., M. B. Kim, C. Kim, and J. K. Hwang. 2018. Inhibitory effects of panduratin A on periodontitis-induced inflammation and osteoclastogenesis through inhibition of MAPK pathways in vitro. J. Microbiol. Biotechnol. 28:190-198. https://doi.org/10.4014/jmb .1707 .07042

Koo, H., J. Seils, J. Abranches, R. A. Burne, W. H. Bowen, and R. G. Quivey Jr.. 2006. Influence of apigenin on gtf gene expression in Streptococcus mutans UA159. Antimicrob. Agents Chemother. 50:542-546. https://doi.org/10.1128/AAC.50.2.542-546.2006.

Koo, H., J. Xiao, M. Klein, and J. Jeon. 2010. Exopolysaccharides produced by Streptococcus mutans glucosyltransferases modulate the establishment of microcolonies within multispecies biofilms. J. Bacteriol. 192:3024-3032. https://doi.org/10.1128/JB.01649-09.

Lai, W. K., Y. C. Lu, C. R. Hsieh, C. K. Wei, Y. H. Tsai, F. R. Chang, and Y. Chan. 2021. Developing lactic acid bacteria as an oral healthy food. Life (Basel) 11:268. https://doi.org/10.3390/ life11040268.

Lee, J. S., I. K. Hyun, H. J. Seo, D. Song, M. Y. Kim, and S. S. Kang. 2021a. Biotransformation of whey by Weissella cibaria suppresses 3T3-L1 adipocyte differentiation. J. Dairy Sci. 104:3876-3887. https://doi.org/10.3168/jds.2020-19677.

Lee, J. S., I. K. Hyun, J. W. Yoon, H. J. Seo, and S. S. Kang. 2021b. Bioconversion products of whey by lactic acid bacteria exert antiadipogenic effect. Food Sci. Anim. Resour. 41:145-152. https://doi .org/10.5851/kosfa.2020.e78.

Liang, L., J. Yu, W. Zhou, N. Liu, L. L. e, D. S. Wang, and H. Liu. 2014. Endothelin-1 stimulates proinflammatory cytokine expression in human periodontal ligament cells via mitogen-activated protein kinase pathway. J. Periodontol. 85:618-626. https://doi .org/10.1902/jop.2013.130195.

Ma, Y., J. Liu, H. Shi, and L. L. Yu. 2016. Isolation and characterization of anti-inflammatory peptides derived from whey protein. J. Dairy Sci. 99:6902-6912. https://doi.org/10.3168/jds.2016-11186.

Madureira, A. R., C. I. Pereira, A. M. Gomes, M. E. Pintado, and F. X. Malcata. 2007. Bovine whey proteins-Overview on their main biological properties. Food Res. Int. 40:1197-1211. https://doi .org/10.1016/j.foodres.2007.07.005.

Madureira, A. R., T. Tavares, A. M. Gomes, M. E. Pintado, and F. X. Malcata. 2010. Invited review: physiological properties of bioactive peptides obtained from whey proteins. J. Dairy Sci. 93:437-455. https://doi.org/10.3168/jds.2009-2566.

Martin, M., J. Katz, S. N. Vogel, and S. M. Michalek. 2001. Differential induction of endotoxin tolerance by lipopolysaccharides derived from Porphyromonas gingivalis and Escherichia coli. J. Immunol. 167:5278-5285. https://doi.org/10.4049/jimmunol.167 9.5278 .

Mendi, A., S. Kose, D. Uckan, G. Akca, D. Yilmaz, L. Aral, S. E. Gultekin, T. Eroglu, E. Kilic, and S. Uckan. 2016. Lactobacillus rhamnosus could inhibit Porphyromonas gingivalis derived CXCL8 attenuation. J. Appl. Oral Sci. 24:67-75. https://doi.org/10.1590/ $1678-775720150145$.

Minj, S., and S. Anand. 2020. Whey proteins and its derivatives: Bioactivity, functionality, and current applications. Dairy 1:233-258. https://doi.org/10.3390/dairy1030016.

Nativel, B., D. Couret, P. Giraud, O. Meilhac, C. L. d'Hellencourt, W. Viranaicken, and C. R. Da Silva. 2017. Porphyromonas gingivalis lipopolysaccharides act exclusively through TLR4 with a resilience between mouse and human. Sci. Rep. 7:15789. https://doi.org/10 $.1038 / \mathrm{s} 41598-017-16190-\mathrm{y}$

Netea, M. G., M. van Deuren, B. J. Kullberg, J.-M. Cavaillon, and J. W. Van der Meer. 2002. Does the shape of lipid A determine the interaction of LPS with Toll-like receptors? Trends Immunol. 23:135-139. https://doi.org/10.1016/S1471-4906(01)02169-X.

Peres, M. A., L. M. Macpherson, R. J. Weyant, B. Daly, R. Venturelli, M. R. Mathur, S. Listl, R. K. Celeste, C. C. Guarnizo-Herreño, C. Kearns, H. Benzian, P. Allison, and R. G. Watt. 2019. Oral diseases: A global public health challenge. Lancet 394:249-260. https: //doi.org/10.1016/S0140-6736(19)31146-8.

Pitts, N. B., D. T. Zero, P. D. Marsh, K. Ekstrand, J. A. Weintraub, F. Ramos-Gomez, J. Tagami, S. Twetman, G. Tsakos, and A. Ismail. 2017. Dental caries. Nat. Rev. Dis. Primers 3:17030. https:// doi.org/10.1038/nrdp.2017.30.

Salles Branco-de-Almeida, L., R. Murata, E. Franco, M. dos Santos, S. de Alencar, H. Koo, and P. Rosalen. 2011. Effects of 7-epiclusianone on Streptococcus mutans and caries development in rats. Planta Med. 77:40-45. https://doi.org/10.1055/s-0030-1250121.

Sawada, S., N. Chosa, A. Ishisaki, and K. Naruishi. 2013. Enhancement of gingival inflammation induced by synergism of IL-1 $\beta$ and IL-6. Biomed. Res. 34:31-40. https://doi.org/10.2220/biomedres .34.31.

Schilling, K. M., and W. H. Bowen. 1992. Glucans synthesized in situ in experimental salivary pellicle function as specific binding sites for Streptococcus mutans. Infect. Immun. 60:284-295. https://doi .org/10.1128/iai.60.1.284-295.1992.

Simón-Soro, A., and A. Mira. 2015. Solving the etiology of dental caries. Trends Microbiol. 23:76-82. https://doi.org/10.1016/j.tim 2014.10.010.

Strauss, F.-J., I. Espinoza, A. Stähli, M. Baeza, R. Cortés, A. Morales, and J. Gamonal. 2019. Dental caries is associated with severe periodontitis in Chilean adults: A cross-sectional study. BMC Oral Health 19:278. https://doi.org/10.1186/s12903-019-0975-2.

Subramenium, G. A., K. Vijayakumar, and S. K. Pandian. 2015. Limonene inhibits streptococcal biofilm formation by targeting surfaceassociated virulence factors. J. Med. Microbiol. 64:879-890. https: //doi.org/10.1099/jmm.0.000105.

Sun, M., Y. Ji, Z. Li, R. Chen, S. Zhou, C. Liu, and M. Du. 2020. Ginsenoside Rb3 inhibits pro-inflammatory cytokines via MAPK/ AKT/NF-kappaB pathways and attenuates rat alveolar bone resorption in response to Porphyromonas gingivalis LPS. Molecules 25:4815. https://doi.org/10.3390/molecules25204815.

Tavares, T., H. Spindola, G. Longato, M. Pintado, J. Carvalho, and F. Malcata. 2013. Antinociceptive and anti-inflammatory effects of novel dietary protein hydrolysate produced from whey by proteases of Cynara cardunculus. Int. Dairy J. 32:156-162. https://doi .org/10.1016/j.idairyj.2013.05.010.

Van Snick, J. 1990. Interleukin-6: An overview. Annu. Rev. Immunol. 8:253-278. https://doi.org/10.1146/annurev.iy.08.040190.001345.

Wang, X., H. Peng, Y. Huang, W. Kong, Q. Cui, J. Du, and H. Jin. 2020. Post-translational modifications of IkappaBalpha: The state 
of the art. Front. Cell Dev. Biol. 8:574706. https://doi.org/10 $.3389 /$ fcell.2020.574706.

Wang, Y., X. Huang, and F. He. 2019. Mechanism and role of nitric oxide signaling in periodontitis. Exp. Ther. Med. 18:3929-3935. https://doi.org/10.3892/etm.2019.8044.

Won, J. H., H. T. Im, Y. H. Kim, K. J. Yun, H. J. Park, J. W. Choi, and K. T. Lee. 2006. Anti-inflammatory effect of buddlejasaponin IV through the inhibition of iNOS and COX-2 expression in RAW 264.7 macrophages via the NF-kappaB inactivation. Br. J. Pharmacol. 148:216-225. https://doi.org/10.1038/sj.bjp.0706718.

Wu, C. C., C. T. Lin, C. Y. Wu, W. S. Peng, M. J. Lee, and Y. C. Tsai. 2015. Inhibitory effect of Lactobacillus salivarius on Streptococcus mutans biofilm formation. Mol. Oral Microbiol. 30:16-26. https:// doi.org/10.1111/omi.12063.

Zhang, G., M. Lu, R. Liu, Y. Tian, V. H. Vu, Y. Li, B. Liu, A. Kushmaro, Y. Li, and Q. Sun. 2020. Inhibition of Streptococcus mutans biofilm formation and virulence by Lactobacillus plantarum K41 isolated from traditional Sichuan pickles. Front. Microbiol. 11:774. https://doi.org/10.3389/fmicb.2020.00774
Zhang, J., C. Yu, X. Zhang, H. Chen, J. Dong, W. Lu, Z. Song, and W. Zhou. 2018. Porphyromonas gingivalis lipopolysaccharide induces cognitive dysfunction, mediated by neuronal inflammation via activation of the TLR4 signaling pathway in C57BL/6 mice. J. Neuroinflammation 15:37. https://doi.org/10.1186/s12974-017-1052-x.

Zhou, L. M., J. Y. Xu, C. P. Rao, S. Han, Z. Wan, and L. Q. Qin. 2015. Effect of whey supplementation on circulating C-reactive protein: A meta-analysis of randomized controlled trials. Nutrients 7:1131-1143. https://doi.org/10.3390/nu7021131.

\section{ORCIDS}

Dahyun Song (1) https://orcid.org/0000-0001-6032-817X

Geun-Bae Kim @ (https://orcid.org/0000-0001-8531-1104

Seok-Seong Kang ๑ https://orcid.org/0000-0001-7029-9122 